\title{
Islam dan Radikalisme \\ (Mengurai Makna Terorisme)
}

\author{
Muh. Barid Nizarudin Wajdi \\ STAI Miftahul Ula Nganjuk
}

Baridnizar84@gmail.com

\begin{abstract}
Terrorism is a strategy to reach out special golt by using threat violence to appear feeling afraid and to fall victim more and more irregularly. Terrorism as movement what bring truth ambitious, using kind of tools. There is using tool of religion, politic and economic. No matter what tool, terrorism appears character what always hegemony, anarchies, and radical.

While jihad has purpose constructive althought in reaching must there is war. In this matter, jihad has to do in condition to defend State from enemy attact or there is destructive attact from other side what threat life survival and relegion.
\end{abstract}

Keyword : explain, meaningfull, terrorism.

\section{A. Pendahuluan}

Terorisme sebagai sebuah paham memang berbeda dengan kebanyakan paham yang tumbuh dan berkembang di dunia, baik dulu maupun yang mutakhir. Terorisme selalu identik dengan teror, kekerasan, ekstrimitas dan intimidasi. Para pelakunya biasa disebut sebagai teroris. Karena itu, terorisme sebagai paham yang identik dengan teror seringkali menimbulkan konsekuensi negatif dan destruktif bagi kemanusiaan. Terorisme kerap menjatuhkan korban kemanusiaan dalam jumlah yang tak terhitung. Karena itu, hampir semua negara di seluruh penjuru dunia ini membenci kata terorisme dan segala derivasinya, terutama setelah terjadinya peristiwa pengeboman gedung WTC pada 11 September 2001. Mereka memahami dan meyakini bahwa terorisme adalah tindak kejahatan yang besar dilihat dari aspek manapun, bahkan hampir dalam di semua media massa sepakat untuk memeranginya tanpa pernah ada usaha untuk mencari penjelasannya.

Terkait pada pembahasan tentang terorisme hingga kini menjadi perdebatan yang panjang, baik yang pro maupun yang kontra. Menurut pendapat yang mendukung tentang teroris me ini, terorisme merupakan bagian dari jihad fi sabilillah. Sedangkan disisi lain, ada yang kontra mengenai hal ini dengan alasan bahwa terorisme bertolak belakang dengan ajaran Islam. Teroris me berbeda dengan Jihad baik dari segi makna, cara, tujuan dan sasarannya.

\section{B. Pengertian Te roris me}

Dalam Bahasa Arab, terorisme dikenal dengan istilah Al-Irhab. Dari sini, bisa dipahami bahwa kata Al-Irhab (teror) berarti (menimbulkan) rasa takut. Irhabi (teroris) artinya orang yang membuat orang lain ketakutan, orang yang menakut-nakuti orang lain. Sedangkan dalam Kamus Besar Bahasa Indonesia, terorisme adalah puncak aksi kekerasan, terrorism is the apex of violence. Selain itu, terorisme adalah Penggunaan kekerasan untuk menimbulkan ketakutan, dalam usaha mencapai suatu tujuan (terutama tujuan politik). Sedangkan teroris adalah orang yang menggunakan kekerasan untuk menimbulkan rasa takut (biasanya untuk tujuan politik), dan teror adalah perbuatan sewenang-wenang, kejam, bengis, dalam usaha menciptakan ketakutan, kengerian oleh seseorang atau golongan.

Selain itu, ada beberapa definisi tentang terorisme antara lain:

1. Menurut Konvensi PBB tahun 1937, terorisme adalah segala bentuk tindak kejahatan yang ditujukan langsung kepada negara dengan maksud menciptakan bentuk teror terhadap orangorang tertentu atau kelompok orang atau masyarakat luas.

2. Menurut US Federal Bureau of Investigation (FBI), terorisme adalah penggunaan kekuasaan tidak sah atau kekerasan atas seseorang atau harta untuk mengintimidasi sebuah 
pemerintahan, penduduk sipil dan elemen-elemennya untuk mencapai tujuan-tujuan sosial atau politik.

3. Menurut Muhammad Mustofa, terorisme adalah tindakan kekerasan atau ancaman kekerasan yang ditujukan kepada sasaran secara acak (tidak ada hubungan langsung dengan pelaku) yang berakibat pada kerusakan, kematian, ketakutan, ketidakpastian dan keputusasaan massal.

4. Peraturan Pemerintah Pengganti Undang-Undang Republik Indonesia Nomor 2 Tahun 2002 tentang Pemberantasan Tindak Pidana Terorisme, dinyatakan bahwa terorisme merupakan kejahatan terhadap kemanusiaan dan peradaban serta merupakan salah satu ancaman serius terhadap kedaulatan setiap negara, karena terorisme sudah merupakan kejahatan yang bersifat internasional yang menimbulkan bahaya terhadap keamanan, perdamaian dunia serta merugikan kesejahteraan masyarakat sehingga perlu dilakukan pemberantasan secara berencana dan berkesinambungan sehingga hak asasi orang banyak dapat dilindungi dan dijunjung tinggi.

Jadi kesimpulannya dari beberapa definisi diatas, terorisme merupakan suatu cara untuk mencapai tujuan tertentu dengan menggunakan ancaman kekerasan guna menimbulkan rasa takut dan menjatuhkan korban sebanyak-banyaknya secara tidak beraturan.

\section{Akar Sejarah Kata Terorisme}

Berkembangnya terorisme ditandai dengan bentuk fanatisme aliran kepercayaan yang kemudian berubah menjadi pembunuhan, baik yang dilakukan secara perorangan maupun oleh suatu kelompok terhadap penguasa yang dianggap sebagai tiran. Pembunuhan terhadap individu ini sudah dapat dikatakan sebagai bentuk murni dari Terorisme dengan mengacu pada sejarah Terorisme modern. Walaupun is tilah Teror dan Terorisme baru mulai populer abad ke-18, namun fenomena yang ditujukannya bukanlah baru. Menurut Grant Wardlaw dalam buku Political Terrorism (1982), manifestasi Terorisme sistematis muncul sebelum Revolusi Perancis, tetapi baru mencolok sejak abad ke-19. Dalam suplemen kamus yang dikeluarkan Akademi Perancis tahun 1798, terorisme lebih diartikan sebagai sistem rezim teror. Kata Terorisme berasal dari Bahasa Perancis "le terreur" yang semula dipergunakan untuk menyebut tindakan pemerintah dari hasil Revolusi Perancis yang mempergunakan kekerasan secara brutal dan berlebihan dengan cara memenggal 40.000 orang yang dituduh melakukan kegiatan anti pemerintah. Selanjutnya kata Terorisme dipergunakan untuk menyebut gerakan kekerasan anti pemerintah di Rusia.

Dengan demikian, kata Terorisme sejak awal dipergunakan untuk menyebut tindakan kekerasan oleh pemerintah maupun kegiatan yang anti pemerintah. Terorisme muncul pada akhir abad ke-19 dan menjelang terjadinya Perang Dunia I, terjadi hampir di seluruh belahan dunia. Sejarah mencatat pada tahun 1890 -an aksi terorisme di Armenia melawan pemerintah Turki, yang berakhir dengan bencana pembunuhan masal terhadap warga Armenia pada Perang Dunia I. Pada dekade tersebut, aksi terorisme diidentikkan sebagai bagian dari gerakan sayap kiri yang berbasiskan ideologi karena Mereka percaya bahwa terorisme adalah cara yang paling efektif untuk melakukan revolusi politik maupun sosial, dengan cara membunuh orang-orang yang berpengaruh.

Kemudian setelah pasca Perang Dunia II, dunia tidak pernah mengenal “damai”. Berbagai pergolakan berkembang dan berlangsung secara berkelanjutan. Konfrontasi negara adikuasa yang meluas menjadi konflik Timur - Barat dan menyeret beberapa negara Dunia Ketiga ke dalamnya menyebabkan timbulnya konflik Utara - Selatan sehingga dapat membuat dunia bergejolak. Ketidakstabilan dunia dan rasa frustasi dari Negara Berkembang dalam menuntut hak-hak yang dianggap fundamental dan membuka peluang untuk muncul dan meluasnya terorisme. Fenomena terorisme meningkat sejak permulaan dasa warsa 70-an. Terorisme dan teror telah berkembang dalam sengketa ideologi, fanatisme agama, perjuangan kemerdekaan, dan pemberontakan. Bahkan juga terorisme oleh pemerintah dianggap sebagai cara dan sarana menegakkan kekuasaannya. Teroris me gaya baru mengandung beberap a karakteristik;

1. Ada maksimalisasi korban yang sangat mengerikan. Keinginan untuk mendapatkan liputan di media massa secara internasional dengan cepat.

2. Tidak pernah ada yang membuat klaim terhadap terorisme yang sudah dilakukan. 
3. Serangan terorisme itu tidak pernah bisa diduga karena sasarannya sama dengan luasnya seluruh permukaan bumi.

\section{Bentuk-bentuk Te roris me}

Terorisme diartikulasikan dalam tiga bentuk. Pertama, terorisme yang bersifat personal. Aksi-aksi terorisme dilakukan perorangan. Biasanya, dalam pengeboman bus merupakan sebuah aksi personal. Pengeboman mal-mal dan pusat perbelanjaan juga dapat dikatagorikan sebagai terorisme yang dilakukan secara personal. Kedua, terorisme yang bersifat kolektif. Para teroris melakukannya secara terencana. Biasanya, terorisme semacam ini dilembagakan dalam sebuah jaringan yang rapi. Yang sering disebut-sebut sebagai terorisme dalam kategori ini adalah Jaringan al-Qaeda. Sasaran terorisme dalam kategori ini adalah simbol-simbol kekuasaan dan pusat-pusat perekonomian. Ketiga, terorisme yang dilakukan negara. Istilah ini tergolong baru, yang biasa disebut dengan "terorisme (oleh) negara" (state terorism). Penggagasnya adalah Perdana Menteri Malaysia, Mahathir Muhammad dalam hajatan OKI terakhir. Menurutnya, terorisme yang dikerahkan negara, tidak kalah dahsyatnya dari terorisme personal maupun kolektif. Kalau kedua bentuk terdahulu dilaksanakan secara sembunyi-sembunyi, terorisme yang dilakukan sebuah negara dapat dilihat secara kasat mata.

Ketiga-tiganya mempunyai titik temu, yaitu sama-sama mencari tumbal dan korban. Yang mencolok dalam terorisme adalah "balas dendam". Karenanya, terorisme identik dengan kenekatan dan keterpanggilan untuk melawan secara serampangan, yang penting ada korban.

Di sini sebenarnya ranah problematis terorisme. Terorisme ibarat singa yang selalu haus mangsa. Sebagaimana singa, terorisme tidak bisa mengambil "jalan tengah", melainkan menempuh "jalan pintas". Sebab para teroris, biasanya melandaskan pada kebutuhan untuk membangun sebuah menara yang disebut "identitas yang tunggal". Terorisme mengandaikan adanya "absolutisme", baik dalam tataran suprastruktur maupun struktur.

Terorisme sebagai gerakan yang membawa ambisi kebenaran, menggunakan pelbagai kendaraan. Ada yang menggunakan kendaraan agama, politik dan ekonomi. Apapun kendaraannya, terorisme menampilkan wataknya yang serba hegemonik, anarkis dan radikal. Inilah kesan yang bisa ditangkap mengenai terorisme. Hampir seluruh gambarannya buruk dan tidak manusiawi.

\section{E. Teroris me dalam Pers pektif Al-Qur'an}

Ajaran Islam adalah ajaran yang mendatangkan rahmat bagi umat manusia. Allah ta'ala berfirman (yang artinya), "Tidaklah Kami mengutus engkau melainkan sebagai rahmat bagi seluruh umat manusia." (QS.21: 107). Ibnu Abbas menerangkan bahwa rahmat tersebut bersifat umum mencakup orang yang baik-baik maupun orang yang jahat. Barang siapa yang beriman kepada beliau -Nabi Muhammad- maka akan sempurnalah rahmatnya di dunia sekaligus di akhirat. Adapun orang yang kufur kepadanya maka hukuman -yang sesungguhnya- akan disisihkan darinya sampai datangnya kematian dan hari kiamat (lihat Zaad al-Masir [4/365] asSyamilah)

Di antara bukti kasih sayang Islam kepada umat manusia adalah Islam tidak membenarkan penumpahan darah manusia tanpa alasan yang benar. Allah ta'ala berfirman (yang artinya), "Janganlah kamu membunuh nyawa yang diharamkan Allah -untuk dibunuh- kecuali dengan sebab yang benar." (QS. 6: 151). al-Baghawi menjelaskan bahwa di dalam ayat ini Allah mengharamkan membunuh seorang mukmin dan mu'ahad -orang kafir yang terikat perjanjian keamanan dengan umat Islam- kecuali dengan sebab yang benar yaitu sebab-sebab yang membuat orang itu boleh dibunuh seperti karena murtad, dalam rangka qishash -bunuh balas bunuh-, atau perzinaan yang mengharuskan hukuman rajam bagi pelakunya (lihat Ma'alim atTanzil [3/203] as-Syamilah)

Rasulullah shallallahu 'alaihi wa sallam bersabda, "Barang siapa yang membunuh seorang kafir yang terikat perjanjian -dengan kaum muslimin atau pemerintahnya- maka dia tidak akan mencium bau surga. Sesungguhnya baunya itu akan tercium dari jarak perjalanan empat puluh tahun." (HR. Bukhari). al-Munawi menjelaskan bahwa ancaman yang disebutkan di dalam hadits ini merupakan dalil bagi para ulama semacam adz-Dzahabi dan yang lainnya untuk menegaskan bahwa perbuatan itu - membunuh orang kafir mu'ahad- termasuk perbuatan dosa besar (Faidh alQadir [6/251] as-Syamilah). 
Demikian juga Islam tidak memperkenankan perilaku bunuh diri, meskipun dengan niat yang baik, yaitu untuk memerangi musuh- sebagaimana dalam firman-Nya (yang artinya), "Janganlah kamu membunuh dirimu sendiri, sesungguhnya Allah Maha menyayangi dirimu." (QS. 4:29). Rasulullah SAW bersabda, "Barang siapa yang membunuh dirinya dengan sesuatu alat maka dia akan disiksa dengannya pada hari kiamat." (HR. Muslim). Yaitu dia bunuh diri dengan alat untuk membunuh, meminum racun dan lain sebagainya (lihat Tuhfat al-Ahwadzi [6/435] as-Syamilah)

Selain itu, Agama Islam yang suci ini dibawa oleh Rasulullah yang mempunyai kepribadian yang suci pula, serta memiliki akhlaqul karimah dan sifat-sifat yang terpuji, sebagaimana dijelaskan dalam Al-Qur'an (yang artinya)," maka disebabkan rahmat dari Allah lah kamu berlaku lemah-lembut terhadap mereka. Sekiranya kamu bersikap keras lagi berhati kasar, tentulah mereka menjauhkan diri dari sekelilingmu". (QS. 3:159)

Dalam ayat tersebut dijelaskan bahwa Nabi Muhammad SAW memiliki sifat lemah-lembut serta hati beliau terasa amat berat atas penderitaan yang menimpa pada manusia, maka beliau berusaha keras untuk membebaskan dan mengangkat penderitaan yang dirasakan oleh manusia tersebut. Rasulullah SAW bersabda: (yang artinya), "kejahatan dan perbuatan jahat, keduanya sama sekali bukan ajaran Islam. Dan orang yang paling baik Islamnya ialah yang paling baik akhlaqnya". [HR. Ahmad].

Islam juga melarang seorang muslim mengadakan kerusakan di bumi sebagaimana Firman Allah SWT ( yang artinya), "dan apabila ia berpaling (dari kamu), ia berjalan di bumi untuk Mengadakan kerusakan padanya, dan merusak tanam-tanaman dan binatang ternak, dan Allah tidak menyukai kebinasaan". (QS. 2: 205). Sebaliknya Islam menginginkan terciptanya kesatuan umat dan kewajiban mereka masing-masing terhadap yang lain yaitu harus menjaga keselamatan hidup dan kehidupan bersama dan menjauhi hal yang membahayakan orang lain. Dilarang untuk saling membunuh dan meneror sesamanya. Karena membunuh seseorang manusia berarti membunuh manusia seluruhnya, sebagaimana memelihara kehidupan seorang manusia berarti memelihara manusia seluruhnya. Simak apa penutran Al-Quran (yang artinya), "Oleh karena itu Kami tetapkan (suatu hukum) bagi Bani Israil, bahwa: Barangsiapa yang membunuh seorang manusia, bukan karena orang itu (membunuh) orang lain, atau bukan karena membuat kerusakan dimuka bumi, Maka seakan-akan dia telah membunuh manusia seluruhnya. dan Barangsiapa yang memelihara kehidupan seorang manusia, Maka seolah-olah dia telah memelihara kehidupan manusia semuanya......". (QS. 5:32)

Di sisi lain, al-Quran tidak melarang umat Islam untuk membela diri jika mereka diserang dan dikhiyanati. Ibarat peribahasa " jangan cari musuh tapi jika ada musuh jangan lari". Dijelaskan dalam al Qur'an ( yang artinya,) "Mengapa kamu tidak memerangi orang-orang yang merusak sumpah (janjinya), Padahal mereka telah keras kemauannya untuk mengusir Rasul dan merekalah yang pertama mulai memerangi kamu?. Mengapakah kamu takut kepada mereka Padahal Allah-lah yang berhak untuk kamu takuti, jika kamu benar-benar orang yang beriman". (QS. 5: 32)

Pada ayat ini Allah menggalakkan semangat orang-orang mukmin supaya melaksanakan dengan sungguh perintah memerangi kaum musyrikin dan jangan takut kepada mereka. Allah menyebutkan tiga sebab utama yang membuktikan bahwa orang-orang musyrik tidak bisa didiamkan dan dibiarkan saja, yaitu:

1. Mereka melanggar perjanjian Hudaibiyah yang telah mereka adakan dengan Nabi Muhammad SAW dan para sahabatnya untuk tidak berperang selama 10 tahun dan saling tidak boleh mengganggu antara kedua belah pihak dan sekutunya. Tetapi tidak lama berselang setelah perjanjian itu diadakan, maka pihak musyrikin Quraisy telah membantu sekutunya dari Bani Bakar untuk menganiaya suku Khuza'ah dari sekutu Nabi yang tinggal di Mekkah.

2. Sebelum Nabi Muhammad hijrah ke Madinah, kaum musyrikin telah berusaha keras untuk mengusir Nabi Muhammad dari Mekah, memenjarakan atau membunuhnya dengan mempergunakan kekuatan dari suku Quraisy agar keluarga Nabi Muhammad sukar mengadakan penuntutan bela. Merekalah yang memulai lebih dahulu memerangi kaum mukminin di Badar, Uhud, Khandaq, dan lain-lainnya. 


\section{F. Jihad versus Teroris me}

Terorisme (al-irhab) digunakan al-Quran untuk melawan "musuh Tuhan" (QS.8:60). Karenanya, beberapa gerakan Islam Politik yang mempunyai pandangan fundamentalis dan radikalis sering kali menggunakan istilah tersebut untuk melawan "musuh Tuhan". Bagi mereka, Barat disebut sebagai salah satu simbol musuh Tuhan. Kemudian dalam mengidentifikasi musuh, Islam politik menggunakan tiga pandangan mendasar. Pertama, politik sebagai bagian dari Islam. Berpolitik praktis merupakan kewajiban bagi setiap muslim. Ini mengakibatkan setiap muslim harus terlibat dalam politik guna melawan "politik kafir". Kedua, Islam sebagai komunitas yang paling benar, sedangkan yang lain dianggap murtad. Ketiga, kecenderungan untuk memaksakan pandangan dengan "tangan besi", kekerasan, pembunuhan dan perang, yang biasa disebut dengan jihad fi sabililillah.

Persoalan utama yang menjadi pembahasan terorisme dalam pandangan Islam adalah pemaknaan kata "jihad". Maka sekarang ini kita banyak melihat prilaku teror ditujukan kepada asset-asset yang berhubungan dengan Amerika, seperti hotel JW Marriot dan Ritz Calten dll. Dalam benak para aktifis muslim, jihad lebih dipahami dalam kerangka balas dendam karena kafir telah memerangi muslim tanpa batas, maka muslim wajib membalasnya dengan memerangi kafir secara tanpa batas pula. Menurutnya, dalam ketentuan syari'ah, jihad berarti berperang melawan kaum kafir yang memerangi Islam dan kaum muslimin. Konsep inilah yang ia sebut dengan jihad fi sabilillah. Dalam pemahamannya, ayat al-Qur'an pertama tentang jihad yang diturunkan kepada Nabi Muhammad adalah memerangi kaum kafir sebatas yang memerangi Islam. Sebagaimana disebutkan dalam al Quran (yang artinya), "Dan perangilah di jalan Allah orang-orang yang memerangi kamu. Dan janganlah kamu melampaui batas. Sesungguhnya Allah tidak menyukai orang-orang yang melampaui batas". ( QS. 2:190)

Dalam kaitannya di atas, muncul pertanyaan, adakah korelasi fungsional antara Islam dan Terorisme? Bisakah gerakan keagamaan yang diduga dalang terorisme sebagai representasi Islam, baik dalam ranah ajaran maupun pengikutnya?

Menyikapi hal itu, Ketua MUI KH Ma`ruf Amin menyatakan kepada ANTARA, (4/10/2010) bahwa terorisme tidaklah identik dengan Islam. Terorisme, menurut dia, juga bukanlah jihad, dan pihaknya telah mengeluarkan fatwa haram terhadap terorisme. Terorisme merupakan tindakan kejahatan terhadap kemanusiaan dan peradaban yang menimbulkan ancaman serius terhadap kedaulatan negara, bahaya terhadap keamanan, perdamaian dunia serta merugikan kesejahteraan masyarakat.

Terorisme adalah salah satu bentuk kejahatan yang diorganisasi dengan baik (well organized), bersifat trans-nasional dan digolongkan sebagai kejahatan luar biasa (extra-ordinary crime) yang tidak membeda-bedakan sasaran (indiskrimatif). Sedangkan Jihad adalah berjuang dengan sungguh-sungguh. Jihad dilaksanakan untuk menjalankan misi utama manusia yaitu menegakkan agama Allah, dengan cara-cara sesuai dengan garis perjuangan para Rasul dan AlQuran.

Jihad yang dilaksanakan Rasul adalah berdakwah agar manusia meninggalkan kemusyrikan dan kembali kepada aturan Allah, menyucikan qalbu, memberikan pengajaran kepada ummat dan mendidik manusia agar sesuai dengan tujuan penciptaan mereka yaitu menjadi khalifah Allah di bumi. Lebih dari itu, jihad yang paling berat sebenarnya adalah jihad melawan hawa nafsu, sebagaimana tersebut pada QS. 79: 40-41. Maksudnya jihad melawan godaan syetan, mengekang hawa nafsu dari melakukan hal-hal yang haram.

Jihad dalam bentuk perang harus jelas pihak-pihak mana saja yang terlibat dalam peperangan, seperti halnya perang yang dilakukan Nabi Muhammad yang mewakili Madinah melawan Makkah dan sekutu-sekutunya. Alasan perang tersebut terutama dipicu oleh kezaliman kaum Quraisy yang melanggar hak hidup kaum Muslimin yang berada di Makkah (termasuk perampasan harta kekayaan kaum Muslimin serta pengusiran). (lihat QS. 4:75)

Perang yang mengatasnamakan penegakan Islam namun tidak mengikuti Sunnah Rasul tidak bisa disebut Jihad. Sunnah Rasul untuk penegakkan Islam bermula dari dakwah tanpa kekerasan, hijrah ke wilayah yang aman dan menerima dakwah Rasul, kemudian mengaktualisasikan suatu masyarakat Islami (Ummah) yang bertujuan menegakkan Kekuasaan Allah di muka bumi. Jihad dalam bentuk perang dilaksanakan jika terjadi fitnah yang membahayakan eksistensi ummat antara lain berupa serangan-serangan dari luar). Jihad tidak bisa dilaksanakan kepada orang-orang yang tunduk kepada aturan Allah atau mengadakan perjanjian damai maupun ketaatan. Dalam berjihad, diharamkan membunuh anak- anak, wanita, 
orang tua, merusak bangunan, rumah ibadah, pohon, dll. Bandingkan dengan perbuatan sekelompok orang yang mengakibatkan kerusakan dan kematian, tentu ini kita tidak sepakat menyebutnya sebagai bentuk jihad.

Dari segi tujuan, jihad bertujuan konstruktif walaupun dalam pencapaiannya harus ada peperangan. Dalam hal ini, jihad wajib dilakukan dalam kondisi bela Negara dari serangan musuh atau ada serangan destruktif dari pihak lain yang akan mengancam kelangsungan hidup dan agama. Misalnya, jihadnya para syuhada bersama Rasulullah dalam menegakkan Islam (QS. 4:75), Jihadnya rakyat Palestina dalam mempertahankan wilayah dan agamanya atau perjuangan para pahlawan dalam mencapai dan mempertahankan kemerdekaan, serta keutuhan NKRI. Dalam keadaan damai dan tanpa peperangan, kewajiban jihad lebih ditekankan kepada dakwah, serta peningkatan kemampuan intelektual dan spiritualitas umat Islam.

Sedangkan terorisme hanyalah kegiatan sekelompok orang yang tidak memiliki tujuan yang jelas. Islam tidak pernah mengajarkan umatnya memusuhi bangsa atau etnis, karena semuanya merupakan fitrah yang diciptakan oleh Allah (Q.S. 49: 13). Islam hanya memusuhi pandangan kufur yang dipaksakan kepada umatnya, dan umat lain, sehingga menolak kebenaran ilahi (Islam). Maka, penolakan umat Islam pada ideologi setan dan nilai- nilai Barat adalah aspirasi intelektual dan politik yang sah dari setiap Muslim, karena bertentangan dengan identitas dan peradaban Islam. Sebagaimana mereka sendiri juga menolak penjajahan, globalisasi dan perang, karena bertentangan dengan nilai kemanusiaan. Jadi gerakan keagamaan yang diduga dalang dari terorisme tidak bisa merepresentasikan Islam karena mereka telah mereduksi pemahaman Jihad ke dalam bentuk-bentuk teror, sesuatu yang tidak diajarkan bahkan bertentangan dengan ajaran Islam.

\section{G. Kesimpulan}

Setelah kita cermati kembali tentang Islam sekaligus peribadi Rasulullah SAW yang diamanati oleh Allah SWT untuk menyebarkan Islam ke seluruh umat manusia ( rahmatan lil alamin), maka jelas sekali bahwa terorisme sama sekali tidak dikenal, bahkan bertolak belakang dengan ajaran Islam. Terorisme menggunakan kekerasan, kekejaman serta kebengisan dan caracara lain untuk menimbulkan rasa takut dan ngeri pada manusia untuk mencapai tujuan. Sedangkan Islam dengan lemah-lembut, santun, membawa khabar gembira tidak menjadikan manusia takut dan lari, serta membawa kepada kemudahan, tidak menimbulkan kesusahan, dan tidak ada paksaan. Memang kedua hal tersebut mempunyai tujuan yang berbeda. terorisme biasanya digunakan untuk tujuan politik, dan kekuasaan. Sedangkan Islam bertujuan untuk menuntun manusia dalam mencapai kebahagiaan hidupnya dengan dilandasi rasa kasih sayang hanya semata-mata mengharap ridha Allah SWT. Jadi dengan demikian, jelas dan teranglah bahwa terorisme dalam pandangan agama Islam tidak dibenarkan, dan jauh dari tuntunan Islam. Terorisme merupakan kejahatan terhadap banyak orang dan kejahatan terhadap peradaban yang menjadi ancaman bagi segenap bangsa serta musuh dari semua agama. Oleh sebab itu, jihad melawan terorisme menjadi komitmen semua negara dan semua agama di dunia. Wallahu`alam

\section{DAFTAR PUSTAKA}

1. Al-Abidin Hammad dan Suhailah Zain, "Bagaimana Mengatasi Terorisme", (Jakarta: Grafindo, 2005).

2. Abdul Zulfidar Akaha, Lc, ”Terorisme Konspirasi Anti Islam”, (Jakarta: Pustaka AlKautsar, 2005).

3. Al-Qurtubi, Al Jami` li ahkamil qur'an

4. Khafi, Syahdatul, "Terorisme Ditengah Arus Global Demokrasi", (Jakarta: 2006)

5. Muladi, "Demokrasi, HAM dan Reformasi Hukum di Indonesia", (Jakarta: The Habibie Center, 2002).

6. Muhammad Mustofa, "Memahami Terorisme: SuatuPerspektif Kriminolog, Jurnal Kriminologi Indonesia FISIP UI, (Jakarta: 2002).

7. Kamus Besar bahasa Indonesia

8. Maktabah Syamilah

9. Rikard, Bangun, "Indonesia di Peta Terorisme Global”, http;//www.polarhome.com. 
10. Suradji, Adjie, "Terorisme” ( Jakarta: Grafindo, 2006).

11. Wikipedia, sejarah Terorisme

12. http://www.google.com. 